\title{
TINJAUAN SANITASI KOLAM RENANG TIRTA SRINADI KLUNGKUNG TAHUN 2021
}

\section{Ida Ayu Putri Windari ${ }^{1}$, Nyoman Purna ${ }^{2}$}

\begin{abstract}
Tirta Srinadi swimming pool opened on April 13th 2012, located at Banjar Minggir, Gelgel, Klungkung Regency and it has two swimming pools. Preliminary observations showed the swimming pools for toddlers and children, there are floating objects on the water, smell of chlorine scent is too stinging, the floor around the pool is slippery, poorly maintained, no urinal and hand washing in the swimming pool area. This research is conducted to find out the swimming pool sanitation condition which includes the water quality, sanitation facility, and construction of the building. The result is divided into two categories; sanitary condition does not qualify if the score is 0-30,5 and 30,6-61 is qualified. The results showed that Tirta Srinadi Swimming Pool fulfilled the requirements because from 61 items examined; 48 points "Yes" and 13 points "No". The recommendation to management is keep maintaining the cleanliness swimming pool environment and chemicals dosage need to be adjusted to the water volume of the swimming pool to avoid inconvenience on the visitors.
\end{abstract}

Keywords: Public Places, Sanitation, Swimming Pools

\section{PENDAHULUAN}

Meningkatnya hubungan atau kontak orang yang satu dengan yang lainnya maka kemungkinan terjadinya penularan penyakit baik secara langsung maupun tidak langsung akan meningkat ${ }^{1}$. Sanitasi adalah suatu usaha yang mengawasi beberapa faktor lingkungan fisik yang berpengaruh kepada manusia, terutama terhadap hal-hal yang mempunyai efek merusak lingkungan fisik dan kesehatan serta kelangsungan hidup ${ }^{2}$. Sanitasi kolam renang bertujuan untuk memutuskan mata rantai penularan penyakit kepada pengunjung yang disebabkan oleh lingkungan kolam renang maupun akibat kualitas air kolam renang yang kurang memenuhi syarat kesehatan, dengan demikian kualitas air kolam renang merupakan faktor yang penting serta perlu diawasi baik secara fisik, 
kimia, dan mikrobiologi karena air dapat menjadi media utama dalam penularan penyakit diantaranya penyakit kulit, penyakit mata, dan penyakit perut ${ }^{3}$. Pemberian senyawa klor berupa kaporit $(\mathrm{Ca}(\mathrm{OCl} 2))$ yang berfungsi untuk mereduksi zat organik, mengoksidasi logam, dan sebagai desinfeksi terhadap mikroorganisme ${ }^{4}$. Sedangkan penggunaan kaporit dengan konsentrasi yang berlebih dapat meninggalkan sisa klor yang menimbulkan dampak buruk bagi kesehatan ${ }^{5}$.

Dari hasil observasi awal terlihat bahwa kolam renang untuk anak-anak dan kolam renang untuk balita ada benda mengapung di permukaan air, selain itu aroma kaporit dalam kolam renang Tirta Srinadi tercium menyengat hingga membuat tidak nyaman pada penciuman. Lantai pada bangunan di sekitar kolam licin, toilet yang tidak terpelihara serta tidak terdapat urinoir dan tempat mencuci tangan di areal kolam renang Tirta Srinadi. Dari hasil wawancara beberapa pengunjung pada bulan Agustus 2020 menyatakan pernah mengalami mata merah dan kulit kering setelah berenang yang kemungkinan disebabkan oleh air kaporit di kolam renang.

\section{METODE PENELITIAN}

Jenis penelitian yang digunakan adalah penelitian deskriptif yang bertujuan untuk melihat gambaran fenomena (termasuk kesehatan) yang terjadi di dalam suatu populasi tertentu ${ }^{6}$. Metode yang digunakan dalam penelitian ini yakni pengamatan langsung (observasi) serta pemeriksaan secara langsung terhadap beberapa parameter kimia dan fisik air kolam renang.

Untuk mengetahui keadaan sanitasi kolam renang diajukan 61 item observasi yang berbeda dan terdiri dari 4 item pemeriksaan kualitas air 36 item pada fasilitas sanitasi, dan 25 item pada konstruksi bangunan yang kemudian item pada setiap komponen dijumlahkan, sehingga skor tertinggi 61 dan skor terendah 0 (nol). Untuk mengetahui keadaan sanitasi kolam renang item "iya" diberi poin 1 sedangkan item "tidak" tidak diberikan poin atau 0 (nol). 
HASIL DAN PEMBAHASAN

\section{Kualitas Air Kolam Renang}

Hasil pengukuran suhu air kolam renang di kolam renang Tirta Srinadi yaitu pada kolam anak $28^{\circ} \mathrm{C}$ dan pada kolam renang dewasa $29,1^{\circ} \mathrm{C}$ telah memenuhi persyaratan pada parameter suhu yang telah ditetapkan dalam Permenkes RI No. 32 Tahun 2017 suhu yaitu berkisar antara 16-40 ${ }^{\circ} \mathrm{C}^{7}$. Hasil pengamatan parameter kejernihan, air kolam renang termasuk dalam kategori jernih. Air kolam renang diperiksa secara manual dengan meletakkan piringan secchi di dasar kolam renang dan terlihat jelas dilihat dari jarak 5 meter. Pemeriksaan $\mathrm{pH}$ air kolam renang menunjukkan hasil kolam renang dewasa yaitu 7,2 memenuhi persyaratan sedangkan kolam anak diperoleh hasil 6,8 belum memenuhi persyaratan maka kolam renang untuk anak-anak belum memenuhi syarat kualitas air dari segi parameter kimia, pada parameter $\mathrm{pH}$ yang terdapat pada Permenkes 32 Tahun 2017 menyebutkan bahwa kadar parameter $\mathrm{pH}$ yang diperbolehkan adalah 7-7,8.

\begin{tabular}{lllr}
\multicolumn{2}{c}{ Dampak } & yang dapat \\
disebabkan karena & rendahnya & $\mathrm{pH}$ \\
kolam renang & yaitu dapat
\end{tabular}
menyebabkan gangguan kesehatan seperti iritasi mata, kulit terasa kering dan gatal, selain itu juga menyebabkan pemakaian chlorine meningkat, pakaian renang mudah rusak, bahan yang terbuat dari logam terutama besi akan cepat berkarat, dan akan merusak dasar keramik serta mempercepat tumbuhnya lumut ${ }^{8}$.Semakin tinggi $\mathrm{pH}$ air dapat mengakibatkan proses klorinasi tidak efektif, karena 90\% dari asam hipoklorit itu akan mengalami ionisasi menjadi ion hipoklorit. Dengan demikian khasiat desinfektan yang mengalami khlorinasi menjadi lemah atau kurang sehingga masih terdapat bakteri dalam air kolam renang ${ }^{9}$

Pemeriksaan chlor pada air kolam renang diperoleh hasil yaitu pada kolam renang anak 1,2 ppm dan kolam renang dewasa yaitu 3,0 ppm. Hal ini menunjukkan bahwa sisa chlor bebas air kolam renang dewasa di kolam renang tidak memenuhi persyaratan kualitas air dari segi parameter kimia sesuai dengan 
Permenkes RI No. 32 Tahun 2017 bahwa parameter sisa chlor yang diperbolehkan adalah 1-1,5 ppm. Sejalan dengan penelitian Novan $(2015)^{10}$ kadar sisa chlor di kolam renang Umum Kota Semarang belum memenuhi syarat sesuai Peraturan Mentri Kesehatan RI Nomor 416 Tahun 1990 karena memiliki nilai ratarata sisa chlor $>0,5 \mathrm{mg} / \mathrm{l}$. Kadar sisa chlor yang terlalu tinggi dalam air dapat menyebabkan gangguan kesehatan berupa keluhan yang dialami oleh pengguna kolam renang, efek kesehatan yang umum muncul atau dirasakan oleh seseorang sesaat setelah terpapar chlorin antara lain adalah iritasi saluran pernafasan, dada sesak, gangguan pada tenggorokan, batuk, iritasi pada kulit, dan iritasi pada mata ${ }^{10}$.

\section{Fasilitas Sanitasi}

Fasilitas sanitasi kolam renang terdiri dari 36 poin yang telah dibandingkan dengan Peraturan Mentri Kesehatan Republik Indonesia No. 061 Tahun 1991 didapat kategori memenuhi persyaratan, namun dari 36 poin tersebut, ada beberapa poin diantaranya belum memenuhi persyaratan, seperti lantai di pancuran bilas terdapat lumut, tidak tersedia kran di tempat kamar ganti pakaian, tidak terdapat tempat sampah disekitar lokasi aktifitas seperti di toilet, TPS terbuat dari beton, jamban yang tersedia tidak bersih, tidak terdapat tempat cuci tangan yang berdekatan dengan kamar ganti, tidak tersedia gudang khusus dan penempatan bahan kimia tidak terpisah.

\section{Konstruksi bangunan}

Konstruksi bangunan kolam renang yang terdiri dari 25 poin, setelah dibandingkan dengan Permenkes RI No. 061 Tahun 1991 di dapat kategori memenuhi persyaratan ${ }^{11}$. Namun beberapa konstruksi bangunan ada yang tidak memenuhi persyaratan, yaitu : atap bocor, sudut-sudut dinding dan dasar kolam tidak melengkung (conus), tidak tersedia papan loncat.

\section{SIMPULAN}

Simpulan penelitian di Kolam Renang Tirta Srinadi adalah keadaan sanitasi kolam renang memenuhi persyaratan sesuai yang telah ditetapkan oleh Permenkes RI No. 32 
Tahun 2017 dan Permenkes No. 061 Tahun 1991, hasil yang di dapat 61 item yang diperiksa 48 item dengan kategori "Ya" dan 13 item dalam kategori “Tidak". Namun ada beberapa item yang tidak memenuhi persyaratan, yaitu : kadar sisa chlor bebas melebihi baku mutu, pH kolam asam, tidak tersedianya peturasan, tempat sampah tidak berada pada semua lokasi aktifitas, atap bocor, dan jamban atau WC tidak dipelihara dengan baik.
SARAN

Dengan diperolehnya hasil tersebut, untuk meningkatkan kualitas kolam renang Tirta Srinadi terutama dari sudut sanitasi, penulis menyarankan kepada pihak pengelola kolam renang untuk senantiasa meningkatkan kebersihan, melengkapi fasilitas sanitasi, dan memberikan desinfektan sesuai dengan takaran yang dianjurkan. 


\section{DAFTAR PUSTAKA}

1. Mukono. Higiene Sanitasi Hotel

Untuk Keperluan Hygiene

Dan Restorant. (Airlangga

Sanitasi, Kolam Renang Solus

University Press., 2004).

Per Aqua, Dan Pemandian

2. Suparlan. Pengantar

Umum. (2017).

Pengawasan Hygiene Sanitasi

Tempat-Tempat Umum Wisata

Dan Usaha Untuk Umum.

8. Suryatni, G. A. P. S. Tinjauan

Sanitasi Kolam Renang dan

(Duatujuh, 2012).

Tingkat Kenyamanan

Pengunjung di Kolam Renang

3. Effendi, H. Telaah Kualitas Air.

(Yogjakarta, 2003).

Tirta Bayu Kuta Utara Badung.

in (2016).

4. Herawati, D. Penentuan Dosis

Kaporit Sebagai Desinfektan

Dalam Menyisihkan

Konsentrasi Ammonium Pada

Air Kolam Renang. $J$.

9. Abdul Rahman.Elly. Kadar Sisa

Chlor dan Kandungan E.Coli

Air PT. Dream Succes Airindo

SaintHealth 1, (2017).

5. Cita, D. W. Kualitas Air Dan

Keluhan Kesehatan Pengguna

Kolam Renang Di Sidoarjo.

Kesling 7, (2013).

(DAS). in (Universitas

Airlangga, 2007).

10. Novan, E. Tinjauan Sanitasi

Lingkungan Kolam Renang.

Kadar Sisa Khlor, Dam Keluhan

Iritasi Mata Pada Perenang Di

Kolam Renang UmumKota

6. Notoatmodjo, S. Metodelogi

Penelitian Kesehatan. (Rineka

Semarang. in (Universitas

Cipta, 2012).

11. Republik Indonesia No. 061

7. Peraturan Mentri Kesehatan No

32 Tahun 2017. Standar Baku

Mutu Kesehatan Lingkungan

Dan Persyaratan Kesehatan Air

Tahun 1991. Persyaratan

Kesehatan Kolam Renang Dan

Pemandian Umum. (1991). 